Session 2525

\title{
OVERVIEW AND EXPANSION OF PROGRAM FOR ENHANCED DESIGN EXPERIENCE IN 1998-99
}

\author{
Sharif Rahman, Theodore F. Smith, and P. Barry Butler \\ College of Engineering, The University of Iowa, Iowa City, IA 52242
}

\begin{abstract}
This paper describes recent experiences with the expansion of the Program for Enhanced Design Experience (PEDE) at The University of Iowa during the 1998-99 academic year. The PEDE is a joint program between The University of Iowa and industry to enhance the design experience of undergraduate engineering students. In 1998-99, discussions between The University of Iowa and various companies, such as Aluminum Company of America, Hon Industries, John Deere Dubuque Works, Monsanto, and Rockwell Collins, led to eleven design projects and significant expansion of the PEDE. This paper provides a description of the 1998-99 PEDE and discusses how the design projects and teams were selected, the procedures to promote interaction between participants in the PEDE, and the evaluation of the PEDE. End-of-program assessment surveys and graduating senior surveys suggest that the students have gained valuable knowledge about engineering design and current business practices. The evaluation also reveals the need for more effective design review meetings, more resources for computer hardware and software, and stronger commitments of support from lead engineers at various sponsoring companies. Future visions of PEDE and plans for operating PEDE in the 1999-00 academic year are also presented.
\end{abstract}

\section{Introduction}

One characteristic of the engineering discipline that distinguishes it from the science disciplines is engineering design. Practicing engineers in industry spend a considerable amount of time involved with design of a product, process, or system. It is, therefore, essential that undergraduate students preparing for professional careers in engineering be exposed to the concepts of engineering design.

The Accreditation Board for Engineering and Technology $(\mathrm{ABET})^{1}$ defines engineering design as

“... the process of devising a system, component, or process to meet desired needs. It is a decision-making process (often iterative), in which the basic sciences, mathematics, and engineering sciences are applied to convert resources optimally to meet a stated objective. Among the fundamental elements of the design process are the establishment of objectives and criteria, synthesis, analysis, construction, testing, and evaluation. The engineering design component of a curriculum must include 
at least some of the following features: development of student creativity, use of open-ended problems, development and use of design methodology, formulation of design problem statements and specifications, consideration of alternative solutions, feasibility considerations, production processes, concurrent engineering design, and detailed system descriptions. Further, it is essential to include a variety of realistic constraints, such as economic factors, safety, reliability, aesthetics, ethics, and social impact."

In the engineering curricula at The University of Iowa, which are similar to those at other universities in the U.S., undergraduate students are exposed to engineering design concepts in several courses. Their design experience at the undergraduate level culminates with the capstone design course in the senior year ${ }^{2,3}$. The goal of the capstone design course is to integrate all knowledge gained by the students in the engineering and basic sciences courses as well as in the humanities and social science courses and is accomplished by having the students work on a design project. Two weaknesses exist in the current teaching of capstone design courses in most engineering curricula. First, the chosen design projects may not necessarily be real-life or may not relate to a real engineering problem in the field. Hence, it is highly likely that these design projects, when completed, will not advance to the production line. Second, most design projects are required to be completed within one semester. Depending on the scope of a project, a one-semester long time frame may not be adequate when a design project demands a complete cycle of multidisciplinary synthesis, multiphysics analyses, prototyping, testing, and evaluation. Although the current design experience satisfies the minimum ABET requirements, we strongly believe that the design experience could be enhanced by giving students the opportunity to interact with practicing engineers from industry and to work on a yearlong design project. Through this enhanced engineering design experience, the students would be in a position to assume more responsibilities in an industrial environment upon graduation.

This paper describes our recent experiences with the expansion of a unique program that enhances the design experiences at The University of Iowa. The program is integrated with the existing design content of the curriculum and allows students to interact with practicing engineers to receive firsthand knowledge of design procedures followed in industry. Section 2 provides the goals and historical background of the program. Section 3 describes the details of program in 1998-99. Section 4 discusses the evaluation of the program. Section 5 lists the innovation and enhanced learning from this program. Finally, Section 6 describes the future plans and visions of the program.

\section{Program For Enhanced Design Experience}

The Program for Enhanced Design Experience (PEDE) represents a joint effort between The University of Iowa and industrial firms at Iowa to enhance the design experience of undergraduate students at The University of Iowa. The goals of PEDE are to: (1) expose senior undergraduate students to engineering design by having the students work closely with engineers from industry on a design for a product that is scheduled for production, (2) provide industry with a design for a product, and (3) establish a partnership between local and regional industries and The University of Iowa so that all participants gain by learning about each other's working environments. 
Discussions between the representatives from the Department of Mechanical Engineering at The University of Iowa and the John Deere Dubuque Works (JDDW), which has provided design projects for the capstone design courses at several universities, led to the conclusion that it is difficult at times for industry to propose meaningful design projects because of the time limitation of one semester for the capstone design course and because a design project in industry from the conceptualization stage through the engineering stage to the testing and evaluation stage may take several months. The discussions also revealed that there would be a mutual benefit to industry as well as to The University of Iowa to promote greater interaction between the two institutions. To provide design projects that are representative of those in industry and to promote interaction, the PEDE was established in July 1994 ${ }^{4,5,6}$. In 1994-95, JDDW, the only industrial firm at that time, provided three design projects involving twelve undergraduate seniors in mechanical engineering (4 students per team). Since then, JDDW has provided four design projects during each of the 199596, 1996-97, 1997-98 academic years thus allowing sixteen mechanical engineering students to participate each year. Further details of these PEDE and associated design projects are available in References 4-6.

\section{The 1998-99 PEDE and Program Description}

Since it's creation in 1994, PEDE built strong ties between students, faculty, and industry personnel. Our experiences with JDDW from 1994 to 1998 convinced us to develop similar programs with other industrial firms so that more students can participate in PEDE. In 1998-99, discussions between The University of Iowa and various other companies, such as Aluminum Company of America (ALCOA), Hon Industries, Monsanto, and Rockwell Collins, generated six design projects in addition to five design projects provided by JDDW. This led to a significant expansion of PEDE in 1998-99. The students and faculty from the departments of chemical and biochemical engineering, electrical and computer engineering, and mechanical engineering were involved in the 1998-99 PEDE. A brief description of this PEDE is given in the following subsections.

\section{$\underline{\text { Selection of Design Projects }}$}

For meaningful design experience, it is important that the design projects be carefully selected and be of the type where the final result is an integral part of the firm's product line. To initiate the selection process, meetings between the PEDE director, instructors, and lead engineers at the PEDE sponsoring companies were held in the spring and summer periods prior to the start of the 1998-99 PEDE. Within the meetings, the proposed design projects for the forthcoming year were discussed. For companies that were already involved with PEDE (e.g., JDDW in 1997-98), it was felt that at least one engineer should continue from the previous year so that the experience gained by that engineer in working with the students is passed on to the new engineers. When selecting a design project for a particular product, careful attention was given to where the project lies relative to the product cycle. In some cases, a project that involved modifying and improving an existing design on one model to another model was picked. Projects that may have the students working closely with vendors, contractors, or other facilities associated with the sponsoring companies were considered to maximize exposure of students to industry. During the discussions for new design projects, emphasis was given to the projects with a significant design content. A proposed project may have a high degree of interest but a significant portion of the project may be a study or research 
effort that would be needed to support a design effort. Hence, the proposed project was set aside. In one instance, a project was accepted but, due to changing business conditions, a different project was identified two weeks before the start of PEDE. In other cases, projects that appeared to be focused at the beginning of PEDE experienced changes during the nine-month time period because of changing business conditions and marketing inputs. Although these changes may appear disruptive, they were viewed as positive because they provide the students with the additional experience that there is more to a design project than just doing the design itself.

To internationalize PEDE, a pilot project, named Virtual International Design (VID) was also developed in collaboration with the Universite de Provence and Hon Industries. The goals of this PEDE/VID project were to gain an understanding and appreciation of engineering design practices in other countries, to develop personal communication skills necessary to work on a team with students from another countries on a common design project, to understand and master the difficulties of communicating clearly and concisely through electronic media, and to establish an ongoing collaborative design program with universities throughout the world

Table 1 shows the titles of design projects, student affiliations, and names of industrial firms sponsoring projects in 1998-99. JDDW provided five design projects, Hon industries provided two, Monsanto provided two, ALCOA provided one, and Rockwell provided one.

\section{Selection of Students}

The selection of the students for the 1998-99 PEDE was initiated by making formal announcements in the Spring 1998 semester to the junior-level classes. The students were required to indicate their interest in PEDE by submitting to the Director of PEDE a short letter stating their interest and a current resume. The only qualifications imposed on the students for participation in PEDE were that they be in good academic standing, that they be at a point in their academic schedule to take the senior-level courses, and that they be willing to participate actively in PEDE. Each student is associated with a design team comprising 3 or 4 members. The students were required to sign a legal statement about non-disclosure of proprietary information and about patent rights. The students were considered to be employees of the sponsoring companies, thereby allowing them access to all computer codes, databases, vendors, and other information required to undertake a design project.

\section{$\underline{\text { Academic Course Credits }}$}

The students received six semester-hours of academic credit for participating in the PEDE. This credit consists of a capstone design course and a technical elective course, both courses taken for three semester-hours. The students met weekly with their faculty supervisors and at least once every two weeks with the company lead engineers over the nine-month duration of the design projects. The students devoted 10 to 12 hours per week during the academic year to working on the design project, including university breaks. The students satisfied all requirements of the above-mentioned courses including giving class seminars, mid-term and final presentations, and writing proposals and final reports. External judges from the industry other than the ones sponsoring the projects evaluated the final presentations for the design course in the Fall 1998 semester. At the end of the program (May 1999), the students and faculty visited the sponsoring companies to formally present their designs. 
Table 1. Design projects for 1998-99 Program for Enhanced Design Experience

\begin{tabular}{|c|c|c|c|}
\hline No. & $\begin{array}{l}\text { Title of the Design } \\
\text { Project }\end{array}$ & $\begin{array}{l}\text { Student }^{(\mathrm{a})} \\
\text { Affiliation }\end{array}$ & $\begin{array}{l}\text { Sponsoring Company and } \\
\text { Location }\end{array}$ \\
\hline 1 & $\begin{array}{l}\text { Design of a Sideshift Lock } \\
\text { Mechanism for 315SE Backhoe }\end{array}$ & $\mathrm{ME}$ & $\begin{array}{l}\text { John Deere Dubuque Works } \\
\text { Dubuque, IA }\end{array}$ \\
\hline 2 & $\begin{array}{l}\text { Design of a Position Sensing } \\
\text { System }\end{array}$ & ECE & $\begin{array}{l}\text { John Deere Dubuque Works } \\
\text { Dubuque, IA }\end{array}$ \\
\hline 3 & $\begin{array}{l}\text { Design of World-Class Swing } \\
\text { Characteristic for } 310 \text { SE and } 315 \mathrm{SE} \\
\text { Backhoes }\end{array}$ & $\mathrm{ME}$ & $\begin{array}{l}\text { John Deere Dubuque Works } \\
\text { Dubuque, IA }\end{array}$ \\
\hline 4 & $\begin{array}{l}\text { Design of a Modified Carrier Roller } \\
\text { for Crawlers }\end{array}$ & $\mathrm{ME}$ & $\begin{array}{l}\text { John Deere Dubuque Works } \\
\text { Dubuque, IA }\end{array}$ \\
\hline 5 & $\begin{array}{l}\text { Design of a Carrier Roller Arm and } \\
\text { a Tilt Cylinder Guard for Crawlers }\end{array}$ & $\mathrm{ME}$ & $\begin{array}{l}\text { John Deere Dubuque Works } \\
\text { Dubuque, IA }\end{array}$ \\
\hline 6 & $\begin{array}{l}\text { Design of a Tilt-Limiting Chair } \\
\text { Control Mechanism }\end{array}$ & $\mathrm{ME}$ & $\begin{array}{l}\text { Hon Industries } \\
\text { Muscatine, IA }\end{array}$ \\
\hline 7 & $\begin{array}{l}\text { Design of a Personal Environmental } \\
\text { Control System } \\
\text { (b) }\end{array}$ & $\mathrm{ME}$ & $\begin{array}{l}\text { Hon Industries } \\
\text { Muscatine, IA }\end{array}$ \\
\hline 8 & $\begin{array}{l}\text { Design of a Material Transport } \\
\text { System }\end{array}$ & $\mathrm{ME}$ & $\begin{array}{l}\text { Monsanto } \\
\text { Muscatine, IA }\end{array}$ \\
\hline 9 & $\begin{array}{l}\text { Optimization of Heat Exchanger } \\
\text { Networks for CAC Plant }\end{array}$ & $\mathrm{CBE}$ & $\begin{array}{l}\text { Monsanto } \\
\text { Muscatine, IA }\end{array}$ \\
\hline 10 & $\begin{array}{l}\text { Design of a Polishing System for } \\
\text { 100" Hot Mill Deflector Roll }\end{array}$ & $\mathrm{ME}$ & $\begin{array}{l}\text { ALCOA } \\
\text { Davenport, IA }\end{array}$ \\
\hline 11 & $\begin{array}{l}\text { Reengineering of a Current Circuit } \\
\text { Design }\end{array}$ & ECE & $\begin{array}{l}\text { Rockwell Collins } \\
\text { Cedar Rapids, IA }\end{array}$ \\
\hline
\end{tabular}

(a) $\mathrm{CBE}=$ chemical and biochemical engineering; $\mathrm{ECE}=$ electrical and computer engineering; and $\mathrm{ME}=$ mechanical engineering

(b) Hon Industries provided partial funding for this project in Spring 1999. 


\section{Jump-Start Week and University Breaks}

A unique aspect of PEDE is the Jump-Start Week (JSW). After the first year of PEDE, it became apparent that the students needed to get a faster start on the project. Hence, a JSW was created. The JSW brings the students to a higher level of awareness of the operations and facilities at the PEDE sponsoring companies, introduces the students to personnel at these companies, introduces the students to the design projects and lead engineers, and initiates the design process. Also, the students must understand that there are many factors that must be overcome before a design reaches the production stage and must realize that a good design may not pass if it is not cost effective.

During the JSW of the 1998-99 PEDE, the students spent the week prior to the start of classes for the Fall 1998 at the sponsoring companies. A brief outline of the activities for the JSW is given in Table 2. By the end of the first day, the student design teams were formed and each team was connected with the design project and the lead engineers for that project. The second day involved a trip to the demonstration site where the students became familiar with the handling and capabilities of the products produced by the company. Presentations by representatives from these companies on such topics as new engineers; manufacturing; product planning, liability, and support; cost analysis; and testing were given on the mornings of the third and fourth days. In addition, demonstrations were given on how solid modeling, control simulation, and finite element software packages are used at these companies. The afternoon of these days plus all of the fifth day was devoted to working on the design projects. Oral presentations by each design team were held on the afternoon of the fifth day. By the end of JSW, the students acquired a basic working knowledge about the design project and were in a position to undertake the design process when they return to campus.

Because PEDE is a nine-month long effort for the students, the design work must continue regardless of the university breaks, e.g., four-week winter break during December 1998-January 1999 and a week-long spring break during March 1999. These breaks have no connection with the schedules of lead engineers at the sponsoring companies. Hence, the students were required to work during these university breaks to ensure continuity of the work. On the average, the students spent forty hours during these breaks mostly at the company sites. Depending on the schedules of lead engineers and students, the breakdown of their efforts during these two breaks varied. However, most students spent thirty hours during the winter break and ten hours during the spring break.

Financial support was provided to all students for their time and effort during the JSW and university breaks. This includes trips, meals, and lodgings except for JSW.

\section{Interaction}

A three-way interaction, namely, student and instructor, student and engineer, and instructor and engineer was adopted. The students met the course instructors at least once every week when design review meetings were held. The students were in almost daily contact with the project engineers at the sponsoring companies. This contact was through electronic mail, telephone conversations, and face-to-face meetings that averaged about once every two weeks. Most of the face-to-face meetings between the students and engineers were held at the company sites. 
Table 2. Schedule of Jump-Start Week

\begin{tabular}{|c|c|c|c|}
\hline Date & Day & Time & Activity \\
\hline $8 / 16 / 98$ & Sunday & & Students arrive in Company city (optional) \\
\hline 8/17/98 & Monday & $\begin{array}{r}8: 00 \mathrm{am} \\
8: 15 \mathrm{am} \\
8: 45 \mathrm{am} \\
11: 00 \mathrm{am} \\
12: 00 \mathrm{n} \\
1: 00 \mathrm{pm} \\
3: 00 \mathrm{pm} \\
4: 30 \mathrm{pm}\end{array}$ & $\begin{array}{l}\text { Arrive at Company } \\
\text { Overview of Jump-Start Week } \\
\text { Design project by Lead Engineers } \\
\text { Discussions on design project } \\
\text { Lunch } \\
\text { General tour } \\
\text { Design project } \\
\text { Quit }\end{array}$ \\
\hline 8/18/98 & Tuesday & 8:00 am & Various Tours of Company \\
\hline 8/19/98 & Wednesday & $\begin{array}{l}8: 00 \mathrm{am} \\
12: 00 \mathrm{n} \\
1: 00 \mathrm{pm} \\
4: 30 \mathrm{pm} \\
6: 00 \mathrm{pm}\end{array}$ & $\begin{array}{l}\text { Welcome/Introduction/Overview of Company } \\
\text { Lunch } \\
\text { Design project } \\
\text { Quit } \\
\text { Social Hour (Pizza Party) }\end{array}$ \\
\hline 8/20/98 & Thursday & $\begin{array}{l}\text { 8:00 am } \\
9: 00 \mathrm{am} \\
12: 00 \mathrm{n} \\
1: 00 \mathrm{pm} \\
4: 30 \mathrm{pm}\end{array}$ & $\begin{array}{l}\text { Making oral presentations } \\
\text { Design project } \\
\text { Lunch } \\
\text { Design project } \\
\text { Quit }\end{array}$ \\
\hline $8 / 21 / 98$ & Friday & $\begin{array}{r}8: 00 \mathrm{am} \\
10: 00 \mathrm{am} \\
12: 00 \mathrm{n} \\
1: 00 \mathrm{pm} \\
2: 30 \mathrm{pm}\end{array}$ & $\begin{array}{l}\text { Preparation for Wrap-up } \\
\text { Wrap-up: Oral presentation by design team } \\
\text { Lunch } \\
\text { Final design meeting } \\
\text { Quit }\end{array}$ \\
\hline
\end{tabular}


To promote greater interaction between the lead engineers at the sponsoring companies and engineering educators at The University of Iowa, an interaction schedule was planned and is shown in Table 3. The schedule facilitated face-to-face meetings between these people over the one-year duration of PEDE. The meetings allowed all individuals to keep each other up-to-date on the design projects and to provide an environment for interaction so that all participants become aware of each other's activities. These meetings did not interfere, however, with the biweekly face-to-face meetings between the students and design project engineers and the weekly meetings between the students and engineering educators.

\section{PEDE Laboratories}

Two laboratories were created to provide a meeting place and work area for the PEDE design teams. One laboratory, named the John Deere Dubuque Works Enhanced Design Laboratory, houses a number of Unix Workstations and window-based personal computers, a laptop computer, color and monochrome laser printers, digital camera, and other peripherals. The students use this laboratory for communicating with lead engineers at various sponsoring agencies, for preparing the design, for conducting various analyses of the design, and for preparing oral and written reports.

The second laboratory, named ALCOA Videoconferencing Room, provides additional workspace for use as a conference room equipped with a digital projector. The conference room also houses a desktop workstation that is connected to video-conferencing equipment. Using this facility, one can communicate with people from other cities and countries with real-time video images. The video-conferencing equipment has been successfully used to communicate with students and faculty at the Universite de Provence during the Spring 1999 semester.

\section{Time Schedule and Budget}

The time period for the 1998-99 PEDE was one year, commencing July 1, 1998 and terminating June 30, 1999. The time period for the student participation and design projects was from August 16, 1998 to May 18, 1999.

The budget for the PEDE includes funds for director for one-month salary, instructors for 1/4-month salary per design project, two half-time graduate teaching assistants, student stipends during JSW and university breaks, computer software and hardware, travel, and other related expenses. The sponsoring companies provided these funds. Costs associated with materials and usage of the electronic and mechanical shops at The University of Iowa for building prototype hardware for the design projects were not budgeted, but were expected to be provided by the sponsoring companies, upon consultation with the representatives from sponsoring companies, if necessary. Also, costs for lead engineers' time at sponsoring companies, testing and evaluation expenses, and instructors' time for the courses were not considered. The matching support from The University of Iowa involved graduate teaching assistants, computer software and hardware, telephone, photocopying, general supplies, disk storage, and others. The University of Iowa waived the indirect costs. 
Table 3. Interaction schedule

Month

July 1998

August 1998

September 1998

October 1998

November 1998

December 1998

January 1999

February 1999

March 1999

April 1999

May 1999

June 1999

\section{Meetings}

PEDE coordinator visits sponsoring company

PEDE coordinator visits sponsoring company for JSW

Lead engineer visits The University of Iowa

Lead engineer visits The University of Iowa

PEDE coordinator and instructor visit sponsoring company

Lead engineer visit The University of Iowa

PEDE director, coordinator, instructor, and design team visit sponsoring company for mid-program oral presentation

Lead engineer visits The University of Iowa

PEDE coordinator and instructor visit sponsoring company

Lead engineer visits The University of Iowa

PEDE director, coordinator, instructor, and design teams visit sponsoring company for end-of-program oral presentation

PEDE director and coordinator visit sponsoring company 


\section{Evaluation of 1998-99 PEDE}

\section{End-of-Program Assessment Surveys}

At the conclusion of the PEDE, two assessment surveys were conducted in May 1999. One survey was intended to solicit written responses and the other survey was given to assign numerical scores along with written responses. The original surveys are given in Tables 4 and 5 . The survey forms were sent to all twenty-seven students of seven mechanical engineering design projects 1, 3, 4, 5, 6, 8 , and 10 (see Table 1) that were supervised by the authors. For design projects 2, 9, and 11, other faculty from departments other than mechanical engineering also conducted surveys, but their formats were different from Tables 4 and 5. Hence, their results were not used for the overall assessment of PEDE. For design project 7, no formal survey was performed. Of the twenty-seven students, twenty offered responses to the written part (i.e., survey form in Table 4) and seventeen offered responses to the numerical part (i.e., survey form in Table 5). No effort was made to separate the responses for the seven teams or the four industrial firms that were involved in these surveys.

Table 6 shows the numerical scores to the survey presented in Table 5. The overall score and score for each category are shown. The results indicate high scores for teamwork, learning design, use of engineering tools, and course credit. The interactions with lead engineers and instructors also scored high, but improvements are needed. The activities for JSW did not score as high and will need further improvements. It is worth mentioning that during JSW, some students were disappointed at not being able to drive any of the machines due to the wet weather during the plant trip. Note, these numerical scores were not calibrated with any qualitative performance measure.

From the written responses, most students felt that PEDE experience was a good one. Some students felt that they know more about design development and implementation having been in PEDE. It was also beneficial to most students to gain some "real-world" experience offered by PEDE. Being in PEDE was cited as a great resume builder and a great chance to work with real engineers and an actual company. To some, learning about product management and how industry differs from academia was one of the most beneficial aspects of participating in the PEDE.

As good as PEDE was as an experience, it could use some improvements. Giving each team its own personal computer was one suggestion. There were quite a few suggestions about more interactions between the instructors and the lead engineers and students and lead engineers. Some students felt that the lead engineer was busy for the team and there was not enough contact with the lead engineer. On the other hand, some felt that they had a good working relationship with the lead engineer and felt as if they were treated as equals. It has been suggested that the lead engineer be involved in the weekly design review meetings. Having the lead engineers travel to campus more was also suggested because travel by the students to the different companies takes up most of the day. Some students thought that the instructor's expectations were too high, while others thought that it was nice to work with faculty in a less structured environment.

There were a few comments on the design projects in the surveys. Some teams mentioned the trouble they had with performing large-scale finite element analysis. Some felt that they should be better informed about changes that took place in the middle of the project. 


\section{Table 4. Assessment survey for written response}

\section{ASSESSMENT SURVEY-1 FOR \\ 1998-99 Program for Enhanced Design Experience}

\section{May 6, 1999}

To assist in preparing the Program for Enhanced Design Experience (PEDE) for the 1999-2000 academic year, we request input concerning your experience with the 1998-99 PEDE. We would appreciate your response to the following items. Please do not hesitate to add additional comments. Please return the completed survey to 2201 SC by May 10, 1999. We seek 100 percent return. Thank you for your cooperation in attempting to enhance the 1999-2000 PEDE.

What was the most beneficial aspect of the 1998-99 PEDE?

What was the least beneficial aspect of the 1998-99 PEDE?

Did the experience meet your expectations?

yes; no. If yes, how; if no, why?

What should be done to enhance the 1998-99 PEDE?

Would you recommend the PEDE to future participants?

How do you expect the experience to affect your career? 
Table 5. Assessment survey for numerical response

\section{ASSESSMENT SURVEY-2 FOR \\ 1998-99 Program for Enhanced Design Experience}

May 6, 1999

To assist in preparing the Program for Enhanced Design Experience (PEDE) for the 1999-2000 academic year, we request input concerning your experience with the 1998-99 PEDE. We would appreciate your response to the following items. Please do not hesitate to add additional comments. Please return the completed survey to 2201 SC by May 10, 1999. We seek 100 percent return. Thank you for your cooperation in attempting to enhance the 1999-2000 PEDE.

Rate the following aspects of the 1998-99 PEDE on a scale of 1 to 10 with 10 being the highest? Please add written comments.

- Jump-Start Week

- Working relationship with lead engineers

- Working relationship with engineering educators

- Learning about the various aspects of engineering design

- Use of engineering design tools (Pro/E, Pro/Mechanica, NASTRAN, etc)

- Adequacy of academic credit of $6 \mathrm{s.h}$.

- Gaining experience with team work

- Overall experience

Additional comments: 
Table 6. Numerical scores for assessment survey ${ }^{(a)}$

\begin{tabular}{ccccccccc}
\hline & JSW & $\begin{array}{c}\text { Lead } \\
\text { Engineers }\end{array}$ & Instructors & Design & Tools & Credit & $\begin{array}{c}\text { Team } \\
\text { Work }\end{array}$ & Overall \\
\hline & 7 & 8 & 7 & 10 & 10 & 8 & 10 & 7.5 \\
& 9 & 5 & 10 & 8 & 8 & 8 & 10 & 9 \\
& 8 & 8 & 9 & 10 & 8 & 10 & 10 & 9 \\
& 8 & 9 & 9 & 10 & 10 & 9 & 10 & 10 \\
& 8 & 10 & 10 & 9 & 7 & 9 & 9 & 9.5 \\
& 7 & 5 & 8 & 8 & 9 & 5 & 9 & 8 \\
& 8 & 7 & 9 & 10 & 8 & 10 & 10 & 9.5 \\
& 5 & 5 & 6 & 6 & 8 & 5 & 6 & 5 \\
& 9 & 7 & 8 & 8 & 9 & 10 & 10 & 9 \\
& 10 & 8 & 9 & 10 & 8 & 5 & 10 & 9 \\
& 2 & 8 & 6 & 4 & 6 & 6 & 4 & 4 \\
& 5 & 5 & 5 & 8 & 9 & 9 & 9 & 6 \\
& 8 & 10 & 8 & 10 & 9 & 10 & 10 & 9 \\
& 9 & 10 & 8 & 10 & 10 & 9 & 8 & 9 \\
Std. Dev. & 2.2 & 1.8 & 1.7 & 2.2 & 1.5 & 1.9 & 1.9 & 1.9 \\
Total No. & 17 & 17 & 17 & 17 & 17 & 17 & 17 & 17 \\
\hline
\end{tabular}

(a) The score can vary from 1 to 10 with 10 representing the highest performance. The numerical scores were not calibrated with any qualitative performance measure. 


\section{Graduating Senior Survey}

In addition to the aforementioned surveys, all graduating seniors in the College of Engineering at The University of Iowa were asked to provide responses to an independent survey prepared by the Dean's Office. The Dean's Office received 64 responses from the 149 May 1999 graduating seniors. One of the five questions in this survey was "What are the most worthwhile educational experiences?" Seven out of forty-one respondents to this question cited PEDE as the most worthwhile experience during their undergraduate education at The University of Iowa - a further indication that the students view PEDE as a highly desirable experience. The number of citations for PEDE was largest when compared with citations for any other experiences or programs offered by the College of Engineering. The evaluation of PEDE from this survey is an important one because it compares the value of PEDE with other opportunities in the College. Indeed, the PEDE has established itself as a credible program that provides a unique design experience and promotes a greater awareness of the issues faced by industry

\section{$\underline{\text { Other Evaluations }}$}

Following completion of the JSW in August 1998, a customized survey with respect to the schedule at each sponsoring company was also conducted to evaluate the effectiveness of JSW. The results of this survey indicate that the students liked the overall schedule of activities and various plant tours at the sponsoring companies. However, some students felt that there were too many orientations and presentations, which could have been reduced to accommodate more time for design projects. The results of this survey were communicated to the sponsoring companies so that the quality of JSW can be improved during next year's PEDE.

In addition to aforementioned assessments, numerous course-related surveys were also conducted during Fall 1998 and Spring 1999 semesters. Students completed various survey forms and questionnaires to determine effective use of time, development of ideas, ability to decide issues, and overall productivity of the team. The results of these surveys assured the instructors that all PEDE projects were progressing satisfactorily.

\section{Innovation and Enhanced Learning in PEDE}

The PEDE provides a unique capstone design experience to the undergraduate students of The University of Iowa. Since it's inception in 1994, the following teaching innovation and enhanced design experience have been brought to The University of Iowa:

Industrial Design Experience: Because industry values employees with prior industrial experiences, the traditional engineering graduates must look for ways to generate this experience via cooperative or similar programs. The two-semester long PEDE approach offered at The University of Iowa provides a credible industrial experience to the students by working with engineers at a company while they are at school. It should be noted that the experience offered by PEDE comes in the senior year when the students have a significant amount of technical knowledge and are taking more advanced engineering courses. 
Paper Design vs. Real Design: In PEDE, the students always work with real-life design projects that are scheduled for production, if successful. This contrasts to some capstone design projects offered elsewhere, where the design work may end with a technical report. Knowing that a design can translate into production generates further enthusiasm in the work done by the students and faculty.

Modern Computational Tools: Both students and faculty involved with PEDE are exposed to modern information technology and advanced computational tools needed for design. Some of these advanced tools, which are not formally offered in other engineering courses, are useful to make the students more marketable and also to keep faculty abreast of latest technologies.

Management and Communication Skills: The PEDE projects always require a number of written and oral presentations of the design approach and corresponding results. Improving communication skills is a major objective of the PEDE. Oral presentations in the PEDE are given at least three times during each semester and final presentations are given at both The University of Iowa and the sponsoring companies. Written communications consist of a proposal, midterm reports, final reports, status report, and weekly design review reports. Due to close interaction with industry engineers, the students must learn how to mange their time effectively, meet project deadlines, and achieve the milestones of the project. In some cases, the students along with their industrial counterparts are an integral part of a decision making team where various options are graded and the top few are then considered for future work.

Internationalizing the Engineering Curriculum: With the recent success of the PEDE/VID pilot project, one of the future visions of the PEDE is to establish a collaborative program with the universities throughout the world. This would allow developing personal skills of both students and faculty to work on a team with members from another country or culture on a common project. This is one of the major steps currently taken to internationalize the engineering curriculum of The University of Iowa.

Partnership with Industry: By providing industry with a design for a product, the PEDE has made a significant impact in establishing a partnership between local and regional industries and The University of Iowa. Based on this partnership, a faculty at the department of mechanical engineering developed a new course on advanced software in engineering design. Several faculty enhanced their own research programs by involving graduate students on areas or topics suggested by some of these industrial firms who later provided additional funding. One faculty leveraged the PEDE funds as matching funds to acquire additional funds from the Faculty Early Career Development (CAREER) Program of the National Science Foundation.

Because of the nature of PEDE, other academic institutions and industrial firms should be able to establish a similar program and reap all or some of the benefits of PEDE described here. For example, The University of Missouri at Rolla has developed a similar program with the John Deere Davenport Works in August 1997. 


\section{Plans for the 1999-00 PEDE and Future Visions}

\section{International PEDE}

With the exception of students who are directly involved in The University of Iowa Study Abroad Program, the undergraduate students at the College of Engineering receive very little exposure to the international aspects of engineering. In contrast, the engineering profession is continually becoming more global ${ }^{7,8}$. Today, many U.S. companies rely heavily on international collaboration in the design, manufacturing, and marketing of their products. In addition, consulting firms engaged in the delivery of engineering services are becoming more involved in international activities ${ }^{9,10}$. It is very important that The University of Iowa graduates must develop engineering and personal skills that will make them more effective workers in an international engineering community.

In Spring 1998 through Spring 1999 semesters, following discussion with the faculty at the Universite de Provence, three pilot projects (one semester-long) associated with PEDE/VID were developed thereby allowing ten Iowa engineering students (three in Spring 1998, four in Fall 1998, and three in Spring 1999) to participate. One of these projects, sponsored by Hon Industries, involved designing a Personal Environment Control system for office spaces in the U.S. and Europe. The pilot project involved biweekly teleconferences between the students from both countries and the weekly face-to-face meetings between The University of Iowa students/faculty and lead engineers at Hon Industries. Furthermore, during the 1999 Spring Break, the students and faculty visited the Universite de Provence for design review meetings. This early success in the pilot project has provided enough motivation for developing a full-blown two-semester long PEDE/VID project during the 1999-00 academic year. This new project will involve students from the Colleges of Engineering, College of Business Administration, and College of Liberal Arts and will be supported by Hon Industries.

\section{$\underline{\text { Multidisciplinary Teams }}$}

In the increasingly competitive global market, the ability to work in the multidisciplinary teams and projects is among the most important traits of emerging new engineers ${ }^{11,12,13,14}$. In a real-life design project, there is rarely a design team involving engineers from a single discipline. The wealth of experiences and skills brought to a team by the diversity of its members are of paramount importance in solving design problems that require multiphysics analyses and multidisciplinary synthesis involving engineering, aesthetics, manufacturing, materials, marketing, recycling, waste management, etc. Clearly, there is a real need for educating students about multidisciplinary engineering design in the engineering curricula. While the needs for such efforts are obvious, so are the obstacles to its effective implementation, such as administrative difficulties in coordinating such a program or the issue of how faculty credits are allocated for participating in such a program.

Since the 1998-99 PEDE has already expanded to other departments (chemical and biochemical engineering and electrical and computer engineering) of the College of Engineering, we are developing design projects with students from at least two engineering departments. For example, in 1999-00, both Monsanto and JDDW are supporting two design projects require students from chemical and biochemical engineering, mechanical engineering, and electrical and computer 
engineering. To extend this multidisciplinary nature of interaction further, we are also developing design projects that require students from other Colleges at The University of Iowa. In 1999-00, Hon Industries are sponsoring two design projects that involve students from the Colleges of Business (Marketing) and Liberal Arts (Industrial Design) with the students from mechanical engineering. Further details of these projects from the 1999-00 PEDE will be published in 2000 following completion of the program.

\section{Action from 1998-99 PEDE Evaluation}

Based on the responses to the assessment surveys for the 1998-99, the following action items are planned for the 1999-2000 PEDE:

- $\quad$ Midterm presentations should focus on new activities performed to date.

- $\quad$ The weekly design review meetings should involve faculty, students, and lead engineers from sponsoring companies. If needed, some of these meetings could be held at company sites.

- The lead engineers should visit campus at least twice per semester. The lead engineer should be more committed to helping the students.

- $\quad$ Each team should be given its own personal computer.

- $\quad$ The jump-start week should allocate more time on the design projects and maybe less time for orientations and presentations.

- The University of Iowa should be able to respond better to hardware requirements for running computationally intensive software packages.

- The design projects should be chosen so that its scope is consistent with the year-long duration of the project

\section{Summary and Conclusions}

Recent experiences with the expansion of a joint program between The University of Iowa and the five industrial firms of Aluminum Company of America, Hon Industries, John Deere Dubuque Works, Monsanto, and Rockwell Collins are described. The objective of this program, known as the Program for Enhanced Design Experience, is to enhance the design experience of undergraduate engineering students at The University of Iowa. End-of-program assessment surveys and graduating senior surveys suggest that the students have gained valuable knowledge about engineering design and current business practices. The evaluation also reveals that there are needs for more effective design review meetings, more resources for computer hardware and software, and stronger commitments of support from lead engineers at various sponsoring companies. Future visions of this program include internationalizing engineering curriculum via virtual international design and developing multidisciplinary design teams. Plans supporting these visions are being pursued to operate the program in the future. Just as industry responds to changing market place to remain competitive, it is expected that the program will undergo continued development. 


\section{Acknowledgments}

We gratefully acknowledge the financial support and in-kind support from our sponsoring companies: Aluminum Company of America, Hon Industries, John Deere Dubuque Works, Monsanto, and Rockwell Collins. We thank the following people who helped develop the 1998-99 PEDE: Professor Dong Chyung, Mr. Jack Clark, Mrs. Jenny Dominguez, Mr. Bill Kackley, Mr. Bill Lewis, Mr. Larry McMullen, Mr. Wayne Miller, Professor Sudhakar Reddy, Mr. David Strohl, Dr. Emad Tanbour, and Professor John Wiencek. We also would like to thank former Dean Richard Miller and Professor L. D. Chen for their general support of PEDE.

We acknowledge the efforts by the following lead engineers for the 1998-99 PEDE: Mr. Jeff Bauer, Mr. Mike Barr, Mr. Bob Clark, Mr. Keith Davis, Mr. Chris Ehlers, Mr. Jacob Foxen, Mr., Jeff Geneser, Mr. Richard Gitter, Mr. Andrew Hill, Mr. Mohibul Hoque, Mr. Luis Jimenez, Mr. Eric Kurtz, Ms. Maria Lauck, Mr. Albert Lin, Mr. Jeff Lussman, Mr. Pat Mulligan, Mr. Ed Panther, Mr. Jim Ross, Mr. Jeff Weida, Mr. Dan Williams, and Mr. Wade Winchip.

We also would like to thank Mr. Adam Cannon, Ms. Emily Young, and Mr. Brian Sanders, PEDE teaching assistants; Mr. Connie Lange and Ms. Sheryl Duncan, PEDE secretaries; and the student participants at The University of Iowa.

\section{References}

1. "Engineering Criteria 2000, Third Edition," Engineering Accreditation Commission of The Accreditation Board for Engineering and Technology, December 1997.

2. Todd, R. H., Magleby, S. P., Sorensen, C. D., Swan, B. W., and Anthony, D. K., "A Survey of Capstone Engineering Courses in North America,” Journal of Engineering Education, Vol. 84, No. 2, pp. 165-174, 1995.

3. Dutson, A. J., Todd, R. H., Magleby, S. P., Sorensen, “A Review of Literature on Teaching Engineering Design Through Project Oriented Capstone Courses,” Journal of Engineering Education, Vol. 86, No. 1, pp. 17-25, 1997.

4. Smith, T. F., McMullen, L. G., and Chen, L. D., "Program for Enhanced Design Experience for Undergraduate Engineering Students," Society of Automotive Engineers, Technical Paper No. 950768, 1995a.

5. Smith, T. F., Chen, L. D., McMullen, L. G., and Lukasik, J. J., "Program for Enhanced Design Experience for Undergraduate Engineering Students: One-Year Review," Proceedings of the 57th Annual ASEE North Midwest Section Meeting, pp. Ia.-1-Ia-8, 1995 b.

6. Smith, T. F., Chen, L. D., McMullen, L. G., and Lukasik, J. J., "Experiences with the Program Enhanced Design Experience," Proceedings of the 58th Annual ASEE North Midwest Section Meeting, pp. IV.B-5.1-5.8, 1996c.

7. Smickler, R. and Sommers, L., "Internationalizing College Curriculum," The Education Digest, $54,1989$.

8. “Taking Business Truly Global,” Boeing News, Vol. 56, No. 27, The Boeing Company, Seattle, Washington, p. 12, 1997.

9. Davidow, W. H., and Malone, M. S., "The Virtual Corporation," Harper Business, New York, New York, 1992.

10. "Students Design Their Way to Asia," EQuad News, Vol. 9, No. 4, Princeton University, Princeton, New Jersey, pp. 4-5, 1997.

11. Nichols, S. P. and Fowler, W. T., "The Mechanical Engineering Design Project Program: An Interdisciplinary Approach," Innovations in Engineering and Design Education, ASME, pp. 271-2274, 1993.

12. Benedict, A. H., Moser, A. T., Murphy, R., Skrinde, R. T., "The User of Interdisciplinary Teams in Successful Engineering Design Projects," Innovations in Engineering and Design Education, ASME, pp. 249-251, 1993.

13. "Briefings," ASEE Prism, p. 11, December 1996

14. “What Emerging Engineers Need to Know?” Mechanical Engineering, p. 66, July 1996. 


\section{Biography}

\section{SHARIF RAHMAN}

Sharif Rahman is an Assistant Professor in the Department of Mechanical Engineering and affiliated with the Center for Computer-Aided Design at The University of Iowa. Professor Rahman has received B.S. degree (1984) from Bangladesh University of Engineering and Technology, a M.S. degree (1986) from Purdue University, and Ph. D. degree (1991) from Cornell University. Before joining Iowa in 1995, he was a Research Scientist at Battelle Columbus Laboratories for almost five years. His current teaching interests are design, reliability analysis, computer-aided engineering, and structural mechanics. His current research interests are probabilistic mechanics and reliability, computational fracture and damage mechanics, reliability-based design and optimization, and stochastic meshless methods.

\section{THEODORE F. SMITH}

Theodore F. Smith is a Professor and Interim Chair in the Department of Mechanical Engineering of the College of Engineering at The University of Iowa and is the Director of the Program for Enhanced Design Experience. Dr. Smith has received B.S. (1963), M.S. (1965), and Ph. D. (1972) degrees from the University of Illinois at Urbana-Champaign. His current teaching interests are in the thermal engineering and engineering design areas. His current research interests are radiative properties and heat transfer, optimal control of thermal systems, and thermal sciences and engineering.

\section{P. BARRY BUTLER}

P. Barry Butler is a Professor in the Department of Mechanical Engineering and Interim Dean of the College of Engineering at The University of Iowa. Dr. Butler has received B.S. (1979), M.S. (1981), and Ph. D. (1984) degrees from the University of Illinois at Urbana-Champaign. His current teaching interests are in the thermal engineering area. His current research interests are field of multi-phase reactive flows, shock propagation, initiation, and combustion of solid propellants and pyrotechnics. He has experience working as a visiting research Fellow for the U.S. Navy and Sandia National Laboratories where he conducted research in the area of solid propellant modeling. 